ISSN: 2231-3354

Received on: 13-06-2012

Revised on: 20-06-2012

Accepted on: 04-07-2012

DO: 10.7324/J APS.2012.2716

Chamundeswari K, S. Saranya andS. Rajagopel

CAS in MarineBiology,

F aculty of MarineSciences,

Annamalai University,

Parangi pettai - 608502 , India.

For Correspondence

Chamunckeswari $K$

Email: dhammercy@yahoo.co.in

\section{Exploration of Potential Antimiorobial Activity of Sea Star Astropecten indicus}

\author{
Chamundesweri K, S. Saranya andS. Rajagopal
}

\begin{abstract}
The antimicrobial activity of crude tissue sample of sea star Astropecten indicus collected from Mudasal Odai, southeast coast of India was evaluated with the testing human microbial pathogens viz., Escherichia coli, Klebsiella pneumonia, K. oxytoca, Staphylococcus aureus, Streptococcus sp., Pseudomonas aeruginosa, Salmonella paratyphi and S. typhi using solvent system methanol and ethyl acetate at the concentrations of 250,500 and $1000 \mu l$ by well diffusion method. The crude methanol extracts showed more active exhibiting broad spectrum of antimicrobial activity than the crude ethyl acetate extracts. The maximum inhibiting zone of $13.44 \pm 0.20$ was observed for bacteria Pseudomonas aeruginosa in the crude obtained from methanol followed by ethyl acetate $11.26 \pm 0.09$ against Klebsiella pneumonia at the concentration of $1000 \mu 1$. Moderate activity was found for all the tested strains at $500 \mu 1$ concentration of both the solvents. Bacterial strains K. oxytoca, Staphylococcus aureus has showed no activity at $250 \mu 1$ for methanol and the zone of inhibition for the tested clinical isolates was lesser than the zone of antibiotics used and no zone was found for the negative control. The present work reveals that, sea star A. indicus has potential antimicrobial activity.
\end{abstract}

Keywords: Sea star, A. indicus, crude extracts, antimicrobial activity, bacterial isolates.

\section{INTRODUCTION}

Ocean has plenty of organisms which are evolved with potential secondary metabolites being used as medicine (Devi et al., 2011; Rajeev Kumar Jha and Xu Zi-rong, 2004). Sponges, ascidians, bryozoans and molluscs are largely used for the production of novel compounds in a larger proportion (Proksch et al., 2002) but only less than $1 \%$ of the isolated compounds examined so far for pharmacological activities from the marine organisms (Fusetani, 2000). The multi resistant nature of pathogens to antibiotic is the serious threat and has stimulated search for novel antimicrobial agents from various natural sources (Laila Abubakar et al., 2012). During the last decade, there has been an increase in research on marine crustaceans, molluscs and echinoderms, particularly interest on their secondary metabolites with desirable antimicrobial properties (Casas et al., 2010; Haug et al., 2002). 
Unexpectedly, echinoderms appear as untapped source in the pursuit of the identification of new and useful products (Petzelt, 2005). Sea stars are benthic free living echinoderm has evolved with rich sources of bioactive metabolites such as steroidal glycosides, steroids, anthraquinones, alkaloids, glycolipids and phospholipids de Marino et al., 1997; Palagiano et al., 1995; Pathirana and Andersen 1986). Especially steroidal glycosides and related compounds are predominant metabolites in sea stars and have a broad variety of biological activities such as cytotoxic, hemolytic, ichthyotoxic, repellent, antineoplastic, antimicrobial, antifungal, antiviral and anti-inflammatory (Andersson et al., 1989; Chludil et al., 2002; Ivanchina et al., 2000; Prokofeva et al., 2003; Wang et al., 2002; Wang et al., 2004). Imbricatine from the sea star Dermasterias imbricata is the first benzyltetrahydroisoquinolone alkaloid from a non-plant source and shows in the NCI human cellline screen (Carte, 1996). Cerebrosides and gangliosides have been reported to exhibit various pharmacological effects including antitumour and neuritogenic activities (Endo et al., 1986; Higuchi et al., 1993; Hirsch and Kashman 1989). Saponins are widespread in sea stars (Iorizzi et al., 2001).

Astropecten indicus are paxillosidan sea stars generally found within the sediments of intertidal and subtitdal regions where they voraciously feed on infaunal molluscs. They widely distributed in the Indian waters and reproduces enormously. India has rich resources of asteroids in the Gulf of Mannar and Palk Bay region but they are not being utilized for any other purpose. Only few studies have been made on the some of the sea stars of Indian waters regarding pharmacological potential (Kanagarajan et al., 2008) and most of the studies are restricted to only taxonomy (Karuppaiyan, 2007). By considering the above mentioned factors, the present work was designed and carried out to assess the potential antimicrobial activity on human pathogens.

\section{MATERIALS AND METHODS}

\section{Sample collection and preparation of extracts}

Live samples of A. indicus were collected from the sea Bay of Bengal at the fish landing center Maudasal Odai (Lat. $11^{\circ} 29^{\prime} \mathrm{N}$; Long. $79^{\circ} 46^{\prime} \mathrm{E}$ ) southeast coast of India during the month of august 2011. Freshly collected samples were immediately washed to remove adhered mud and other particles and brought to the laboratory in a frozen condition. The extraction procedure was followed by modified method of Chellaram et al., (2004). 50gms of chopped tissues samples were placed on the solvent methanol and acetone separately in the ratio of $1: 3(\mathrm{w} / \mathrm{v})$ for $24 \mathrm{hrs}$ at normal room temperature, then extracts were filtered by Whatman filter paper No.1 and the solvents were concentrated by rotary evaporator (VC100A Lark Rotavapor ${ }^{\circledR}$ at $30^{\circ} \mathrm{C}$ ) under reduced pressure and temperature, the resultant residues were stored at $4^{\circ} \mathrm{C}$ for further analysis.

\section{Microorganisms used for screening}

Details of human pathogenic strains used for screening were Escherichia coli, Klebsiella pneumonia, $K$. oxytoca, Staphylococcus aureus, Streptococcus sp., Pseudomonas aeruginosa, Salmonella paratyphi and S. typhi. All the pathogenic bacterial strains were obtained from Raja Muthaiah Medical College and Hospital, Annamalai University.

\section{Antibacterial assay}

The bioassay was carried out using the well diffusion method (Reinheimer et al., 1990). Muller Hinton agar plates are prepared by pouring $15 \mathrm{ml}$ of medium and allowed to solidify. The petri plates are swabbed with $24 \mathrm{hrs}$ old culture of the eight selected bacterial strains. Wells were loaded with 250,500 and $1000 \mu$ of extracts prepared by dissolving $1 \mathrm{mg}$ of crude extracts in $1 \mathrm{ml}$ of distilled water. Streptomycin $400 \mu \mathrm{l}$ was used as positive control and negative control was prepared using distilled water. Plates were incubated for $24 \mathrm{hrs}$ at $37^{\circ} \mathrm{C}$. Zone inhibition was recorded in millimeters and three replicates were maintained.

\section{RESULTS AND DISCUSSION}

The radius of inhibition zone for crude extracts has shown in table $1 \& 2$. Results were expressed with mean and standard deviation by using Microsoft excel. The maximum inhibition zone $13.44 \pm 0.20$ was observed for $P$. aeruginosa at the concentration of $1000 \mu \mathrm{l}$ of crude extraction obtained by methanol and minimum was observed $3.37 \pm 0.03$ for $E$. coli at the concentration of $250 \mu \mathrm{l}$ but no activity has been observed for $K$. oxytoca and $S$. aureus at the concentration of $250 \mu 1$.

The results showed different activity for ethyl acetate extraction. It was higher $11.26 \pm 0.09$ against $K$. pneumonia at the concentration of $1000 \mu 1$ and minimum value was $1.13 \pm 0.06$ against $S$. aureus at $250 \mu \mathrm{l}$. The control showed very good activity against $P$. aeruginosa in methanol extracts and against $K$. pneumonia in ethyl acetate extraction. There is no inhibition zone found for the negative control. The extracts of methanol showed higher antimicrobial activity almost for all the concentrations.

The crude methanol and ethyl acetate extracts of tissue samples of $A$. indicus showed high antimicrobial activity against pathogenic isolates of $P$. aeruginosa and $K$. pneumonia. Moderate activity also obtained for $S$. paratyphi, S. typhi, Streptococuus sp., and $E$. coli. Many enough literatures are supports the activity of sea stars extracts obtained from various geographical locations and many drug discovery projects have screened echinoderms against various human bacterial, fungal, viral and fish pathogens (Sri Kumaran et al., 2011). Prabha Devi et al. (2011) accounted that the body wall extract of sea star Pentaceraster affinis showed considerable activity against Shigella flexineri, Acinetobacter sp., and moderate activity against Sreptococcus pyogenes. They suggested that the compounds inhibited the activity of pathogen may be saponins and saponin like steroid derivatives. James (2010) reported that considerable toxicity is found in the echinoderms and the "crown of thorns" Acanthaster planci is highly toxic to human as well as fish predators. Sri Kumaran et al. (2011) also reported that the butanol extracts of Protoreaster lincki showed high activity against $S$. paratyphi and $K$. pneumonia. Methanolic extracts of $P$. regulus showed activity against $K$. oxytoca. They also stated that various extracts showed activity against fish and 
Table. 1: Methanolic extracts of Astropecten indicus against human pathogen at various concentrations and the zone of inhibition (mm) with Mean and SD.

\begin{tabular}{|c|c|c|c|c|c|c|}
\hline Sl. no & Bacterial pathogens & $250 \mu \mathrm{g} / \mathrm{ml}$ & $500 \mu \mathrm{g} / \mathrm{ml}$ & $1000 \mu \mathrm{g} / \mathrm{ml}$ & Positive control & Negative control \\
\hline $\mathbf{1}$ & Escherichia coli & $3.37 \pm 0.33$ & $3.84 \pm 0.32$ & $8.02 \pm 0.19$ & $22.0 \pm 0.16$ & 0 \\
\hline 2 & Klebsiella pneumonia & $3.50 \pm 0.16$ & $4.57 \pm 0.18$ & $8.26 \pm 018$ & $18.89 \pm 0.06$ & 0 \\
\hline 3 & K. oxytoca & 0.0 & $3.19 \pm 0.03$ & $5.31 \pm 0.01$ & $20.67 \pm 0.35$ & 0 \\
\hline 4 & Staphylococcus aureus & 0.0 & $3.28 \pm 0.14$ & $5.27 \pm 0.09$ & $17.66 \pm 1.45$ & 0 \\
\hline 5 & Streptococcus sp. & $3.54 \pm 0.05$ & $5.04 \pm 0.03$ & $8.03 \pm 0.12$ & $18.25 \pm 0.15$ & 0 \\
\hline 6 & Pseudomonas aeruginosa & $4.35 \pm 0.13$ & $6.62 \pm 0.13$ & $13.44 \pm 0.20$ & $23.77 \pm 0.12$ & 0 \\
\hline 7 & Salmonella paratyphi & $4.03 \pm 0.15$ & $5.99 \pm 0.10$ & $9.36 \pm 0.09$ & $16.39 \pm 0.24$ & 0 \\
\hline 8 & S. typhi & $3.90 \pm 0.02$ & $6.15 \pm 0.04$ & $9.92 \pm 0.04$ & $12.94 \pm 0.04$ & 0 \\
\hline
\end{tabular}

Table. 2: Ethyl acetate extracts of Astropecten indicus against human pathogen at various concentrations and the zone of inhibition (mm) with Mean and SD.

\begin{tabular}{|c|c|c|c|c|c|c|}
\hline Sl. no & Bacterial pathogens & $250 \mu \mathrm{g} / \mathrm{ml}$ & $500 \mu \mathrm{g} / \mathrm{ml}$ & $1000 \mu \mathrm{g} / \mathrm{ml}$ & Positive control & Negative control \\
\hline $\mathbf{1}$ & Escherichia coli & $3.77 \pm 0.04$ & $5.18 \pm 0.02$ & $9.11 \pm 0.05$ & $22.13 \pm 0.11$ & 0 \\
\hline 2 & Klebsiella pneumonia & $5.54 \pm 0.04$ & $8.52 \pm 0.00$ & $11.26 \pm 0.09$ & $22.59 \pm 0.12$ & 0 \\
\hline 3 & K. oxytoca & $1.31 \pm 0.02$ & $3.08 \pm 0.04$ & $6.31 \pm 0.10$ & $14.12 \pm 0.06$ & 0 \\
\hline 4 & Staphylococcus aureus & $1.13 \pm 0.06$ & $3.31 \pm 0.02$ & $6.64 \pm 0.11$ & $14.12 \pm 0.06$ & 0 \\
\hline 5 & Streptococcus sp. & $4.62 \pm 0.02$ & $6.71 \pm 0.04$ & $8.95 \pm 0.14$ & $14.64 \pm 0.09$ & 0 \\
\hline 6 & Pseudomonas aeruginosa & $3.23 \pm 0.06$ & $5.99 \pm 0.03$ & $6.02 \pm 0.07$ & $14.33 \pm 0.06$ & 0 \\
\hline 7 & Salmonella paratyphi & $3.66 \pm 0.06$ & $6.51 \pm 0.09$ & $8.22 \pm 0.06$ & $16.43 \pm 0.15$ & 0 \\
\hline 8 & S. typhi & $3.44 \pm 0.04$ & $5.44 \pm 0.06$ & $7.73 \pm 0.03$ & $11.63 \pm 0.08$ & 0 \\
\hline
\end{tabular}

fungal pathogens. Kanagarajan et al. (2008) assessed the toxicity effect of Stellaster equestris and reported the presence of histamine like compounds which are toxic. The compound which is responsible for the respective activity may be of saponins and glycosides groups.

Rinehart et al. (1981) has documented as about $43 \%$ of 83 unidentified California echinoderms have antimicrobial property. Yeon Jung Jung (2002) reported that the fractions obtained from Asterias amurensis and Asterina pectinifera showed strong activity against various human bacterial and fungal pathogens and also affirmed that the pre-treated fractions with protease showed stronger result than the positive control used. Rajiv Kumar Jha and $\mathrm{Xu}$ Zi-rong (2004) has reviewed various bioactive compounds from sea stars, sea urchin and sea cucumbers and reported that the major compounds in the sea stars are saponins, steroidal glycosides and alkaloids. Li et al. (2010) has reviewed many AMPs (antimicrobial peptides) from echinoderms which has strong antimicrobial activity against bacterial, fungal and viral pathogens.

\section{CONCLUSION}

Based on the assay conducted and surveyed literatures we concluded that the sea star Astropecten indicus has potential antimicrobial activity of many polar compounds particularly against $P$. aeruginosa and $K$. pneumonia. This study is suggesting that many promising compounds which have potential pharmaceutical values from these untapped sources to be evaluated for curing many diseases. A. indicus are underutilized for human usage and they can be explored for other pharmaceutical applications with sustainable conservation.

\section{ACKNOWLEDGEMENT}

The authors are thankful to Prof. T. Balasubramanian Dean, Faculty of Marine Sciences, Annamalai University for necessary facilities provided and authors also thankful to Ministry of Earth Sciences, (OSTC), New Delhi, India for the financial supports.

\section{REFERENCES}

Andersson L., Bohlin L, Iorizzi M, Ricco R, Minale L, MorenoLopez W. Biological activity of saponins and saponin-like compounds from starfish and brittle-stars. Toxicon. 1989, 27:179-188.

Carte BK. Biomedical potential of marine natural products. Bio Sci.1996, 46:271-286.

Casas SM., Comesana P, Cao A, Villalba A. Comparison of antibacterial activity in the hemolymph of marine bivalves from Galicia (NW Spain). J Invertebr Pathol. 2011, 106:343-345.

Chellaram C., Mary Elizabeth Gnanambal, Patterson Edward JK. Antibacterial activity of the winged oyster Pteria chinensis (Pterioida: Pteridae). Indian J Mar Sci. 2004, 33(4):369- 372.

Chludil HD., Seldes AM Maier MS. Antifungal steroidal glycosides from the Patagonian starfish Anasterias minuta: Structureactivity correlations. J Nat Prod. 2002, 65:153-157.

de Marino S., Iorizzi M, Zollo F, Minale L, Amsler CD, Baker $\mathrm{BJ}$, McClintock JB. Isolation, structure elucidation, and biological activity of the steroid oligoglycosides and polyhydroxysteroids from an Antarctic starfish Acodontaster conspiccus. J Nat Prod. 1997, 60:959-966.

Emdo M., Nakagawa M, Hamamoto $\mathrm{Y}$, Ishihara $\mathrm{M}$. Pharmacologically active substances from southern pacific marine invertebrates. Pure Appl Chem.1986, 58:387-394.

Fusetani N. Introduction. In: Drugs from the sea (Ed. N. Fusetani). Basel Karger, 2000, 1-5pp.

Haug T., Kjuul AK, Styrvold OB, Sandsdalen E, Olsen MO, Stensvåg K. Antibacterial activity in Strongylocentrotus droebachiensis (Echinoidea), Cucumaria frondosa (Holothuroidea), and Asterias rubens (Asteroidea). J Invert Pathol. 2002, 81: 94-102.

Higuchi R., Inukai K, Jhou JX, Honda M, Komori T, Tsuji S, Nagai Y. Structure and biological activity of ganglioside molecular species. Liebigs Ann Chem. 1993, 359-366.

Hirsch S., Kashman Y. New glycosphingolipids from marine organisms. Tetrahedron. 1989, 45:1223-1228.

Iorizzi M., de Marino S, Zollo E. Steroidal oligoglycosides from the Asteroidea. Curr Org Chem. 2001, 5:951-973.

Ivanchina NV., Kicha AA, Kalinovsky AI, Dmitrenok PS, Stonik VA, Riguera R, Jimenez C. Hemolytic polar steroidal constituents of the starfish Aphelasterias japonica. J Nat Prod. 2000, 63:1178-1181.

James DB. Marine Poisonous Echinoderms. Fishing Chimes. 2010, 30 (1):39-41.

Kanagarajan U., Bragadeeswaran S, Venkateshvaran K. On some toxinological aspects of the starfish Stellaster equestris (Retzius, 1805). J Venom Anim Toxins incl Trop Dis. 2008, 14 (3):435-449.

Karuppaiyan M. Diversity of Echinoderms along the southeast coast of India. Ph.D., Thesis. Annamalai University. 2007, 266 pp. 
Laila Abubakar., Catherine Mwangi, Jacquiline Uku, Samuel Ndirangu. Antimicrobial activity of various extracts of the sea urchin Tripneustes gratilla (Echinoidea). Afr J Pharmacol Ther. 2012, 1(1):19-23.

Li C., Haug T, Stensvåg K. Antimicrobial peptides in Echinoderms. Inver Survi J. 2010, 132-140.

Paathirana C., Andersen RJ. Imbricatine, an unusual benzyltetrahydroisoquinoline alkaloid isolated from the starfish Dermasterias imbricate. J Am Chem Soc. 1986, 108:8288-8289.

Palagiano E., de Marino S, Minale L, Riccio R, Zollo F. Ptilomycalin A, crambescidin 800 and related new highly cytotoxic guanidine alkaloids from the starfishes Fromia monilis and Celerina heffernani. Tetrahedran. 1995, 3675-3682.

Petzelt, C. (2005). Are Echinoderms of Interest to Biotechnology? In. V. Matranga (Ed.) (series editor W. E. G. Muller) Progress in Molecular and Subcellular Biology; Subseries Marine Molecular Biotechnology. Echinodermata (pp.1-6). New York: SpringerVerlag Berlin Heidelberg.

Prabha Devi., Solimabi Wahidulla, Tonima Kamaat, Lisette D'Souza. Screening marine organisms for antimicrobial activity against clinical pathogens. Ind J Geo-Mar Sci. 2011, 338-346.

Prokof'eva NG., Chikina EL, Kicha AA, Ivanchina NV. Biological activities of steroid glycosides from starfish. Comp Biochem Physiol B. 2003, 134:695-701.

Proksch P., Edrada RA, Ebel R. Drugs from the sea-current status and microbiological Implications. Appl Microbiol Biotechnol. 2002, 59:125-134.
Rajeev Kumar Jha., Xu Zi-rong. Biomedical compounds from Marine organism. Mar Dru. 2004, 2:123-146.

Reinheimer JA., Demkow MR, Candioti MC. Inhibition of coliform bacteria by lactic cultures. Austr J Dairy Technol. 1990, 45:5-9.

Rinehart KL., Shaw PD, Shield LS, Gloer JB, Harbour GC, Koker MES, Samain D, Schwartz RE, Tymiak AA, Swynenberg EG, String Fellow DA, Vavva JJ, Coats JH, Zurenko GE, Kuentzel SL, Li LH, Bakus GJ, Brasca RC, Craft LL, Young DN, Connot JL. Marine naturalproducts as sources of anti-viral, anti-microbial, and anti-neoplastic agents. Pure Appl Chem. 1981, 53:795-817.

Sri Kumaran N., Bragadeeswaran S, Thangaraj S. Antimicrobial Activities in Star Fishes Protoreaster lincki (Blainville, 1830) and Pentaceraster regulus (Muller \& Troschel, 1842) Against Isolated Human, Fish Pathogenic and Biofilm Microorganisms. J Appl Sci Res. 2011, 7(6):818-825.

Wang W., Hong J, Lee C-O, Im KS Jung JH. Cytotoxic sterols and saponins from the starfish Certonardoa semiregularis. J Nat Prod. 2004, 67:584-591.

Wang W., R. Li, N. Alam, Y. Liu, C.-O. Lee, J. Hong, C.K. Lee, K.S Im and J.H. Jung, 2002. New saponins from the starfish Certonardoa semiregularis. J Nat Prod. 65, 1649-1656.

Yeon Jung Jung. Characterization of Bioactive Compounds Obtained from Starfishes. M.Sc., dissertation. Graduate School of Changwon National University. 2002, 67p. 